\title{
Epidemiologie infekcí vyvolaných Clostridium difficile (CDI) v České republice
}

\author{
Marcela Krůtová \\ Ústav lékařské mikrobiologie 2. LF UK a FN Motol, Praha
}

V aktuálním čísle časopisu Vnitřní lékařství autoři Stebel et al upozorňují na nové poznatky v léčbě pacientů s klostridiovou kolitidou a současně shrnují zásadní preventivní opatření pro pacienty v riziku rozvoje primární nebo opakované infekce vyvolané Clostridium difficile (CDI) (1).

Clostridium difficile (Clostridioides difficile), obě označení jsou platná (2), je nejčastějším vyvolavatelem infekčních gastroenteritid spojených s nemocniční péči (3). V prípadě podezření na CDI je nutné indikovat vyšetření stolice. Nedostatečné testování může vést k poddiagnostikování těchto infekcí a tím k dalším epidemiologickým konsekvencím. V současné době je doporučený dvoustupňový testovací algoritmus. U pacientů s nejednoznačným laboratorním výsledkem (vyhledávací citlivý test cílený na průkaz glutamát dehydrogenázy - GDH nebo DNA toxigenních Clostridium difficile je pozitivní, ale prítomnost toxinů A/B není potvrzena) je nutné zohlednit aktuální klinický stav pacienta a další laboratorní nálezy pro odlišení probíhající CDI od kolonizace toxigenním kmenem Clostridium difficile s možnou jinou prríčinou průjmu $(4,5)$. Na ne zcela jednotný prístup k laboratorní diagnostice ukazuje počet provedených testů na prítomnost Clostridium difficile u hospitalizovaných pacientů s průjmem, který je v rámci jednotlivých českých nemocnic variabilní (6-9). Průměrné frekvence testování jsou navíc výrazně nižší $(42,1 ; 39,5 ; 37,3$ a 36,1 testů na 10000 ošetřovacích dní v letech 2012-2016) (6-9) než zjištěná průměrná testovací frekvence v Evropě (65,8 a 42,9 testů na 10 000c ošetřovacích dní v letech 2011-2013 a v roce 2016) $(8,9)$.

Při laboratorní konfirmaci CDI je nutné, pokud to klinický stav pacienta vyžaduje, zahájit specifickou léčbu. Jak upozorňují autoři Stebel et al (1), metronidazol, patřící k 3 základním prípravkům doposud doporučovaných k léčbě CDI, ztrácí na základě revidovaných dostupných dat pozici léku volby pro všechny formy CDI (10). Výjimku tvoří pouze použití metronidazolu u pediatrické populace, která v evropských doporučeních není zahrnuta, ale dostupná data byla revidována Americkou společností pro infekční lékařství a nemocniční epidemiologii (IDSA/ SHEA) (11). Aktualizovaný evropský doporučený postup pro léčbu CDI je nyní ve fázi revize členy Evropské studijní skupiny pro Clostridium difficile (ESGCD) a měl by být k dispozici v tomto roce. $\vee$ návaznosti na tento dokument mohou být pripravena i nová doporučení pro Českou republiku.

S diagnózou CDI nesouvisí pouze zahájení terapie, ale také, jak zdưrazňují autoři Stebel et al (1), je nutné zavedení komplexních protiepidemických opatření k zabránění šiření Clostridium difficile na další vnímavé pacienty. V loňském roce byla publikována aktualizovaná evropská doporučení pro prevenci CDI v akutní nemocniční péči, která stratifikují doporučení pro epidemický nebo endemický výskyt CDI (12). Klíčovými body pro prevenci CDI u hospitalizovaných pacientů je sledování výskytu CDI v čase jak na úrovni oddělení, tak v rámci celé nemocnice, dodržování správné hygieny rukou, kontaktní izolace pacientů, důkladný úklid a dezinfekce. Nezbytnou součástí je racionální antibiotická terapie $v$ rámci nemocničního programu vycházející z koncepce „antimicrobial stewardship“, tedy komplexního př́stupu, jehož cílem je optimalizace podávání antiinfektiv, stejně jako trvalá edukace zaměstnanců a pacientů (12).

Incidence CDI v České republice byla v roce 2016 podle aktuálních dat z Evropského centra pro prevenci a kontrolu infekcí (ECDC) 3,9 př́padů na 10000 ošetřovacích dní (údaje z 19 nemocnic), což je mírně nad zjištěným evropským průměrem (3,2 prípadů na 10000 ošetřovacích dní (údaje z 556 nemocnic 20 zemí)) (9). Jak bylo uvedeno autory Stebel et al (1), počet hlášených prípadů v ČR se po strmém nárůstu od roku 2008 stabilizoval, což potvrzuji i data o incidenci CDI získaná $\checkmark$ rámci evropských a/nebo národních multicentrických studiích $(6-8,13)$. V roce 2008 byla incidence CDI 1,1 prrípadů na 10000 ošetrovacích dní (data z 3 nemocnic) (13) a v letech 2011-2012, 2012-2013 dosáhla již 4,4 a 6,2 prípadů na 10000 ošetřovacích dní (data z 10 nemocnic) (8). V roce 2014 zůstala incidence CDI na stejné úrovni 6,1 prípadů na 10000 ošetřovacích dní (data z 18 nemocnic) (6), ale v roce 2015 dochází k jejímu poklesu na 5,2 prípadů na 10000 ošetřovacích dní (data z 28 nemocnic) (7).

Na současné epidemiologické situaci CDI v ČR se podílí rozšiřrení dvou ribotypů Clostridium difficile, ribotypu 001 a 176 (14). Subtypizace izolátů ribotypů 001 (184 izolátů) a 176 (225 izolátů) pomocí multilokusové analýzy tandemových repetic (MLVA) potvrdila klonální príbuznost 
izolátů Clostridium difficile, která byla pozorována v jednotlivých nemocničních zařízeních tak i mezi nimi, což potvrzuje vyšší potenciál těchto ribotypů k šiření v nemocničním prostředí (6). Ačkoliv výše zmíněné ribotypy (001 a 176) dominující epidemiologické situaci v ČR jsou fylogeneticky odlišné (14) , jejich společným epidemiologickým znakem je popsaná rezistence hned k několika antimikrobním prípravkům a s tím spojená kumulace mechanismů rezistence (15). S výskytem výše zmíněných Clostridium difficile ribotypů (001 a 176) v ČR bylo analýzou 490 CDI epizod z 28 českých nemocnic signifikantně asociováno předchozí

\section{LITERATURA}

1. Stebel R, Vojtilová L, Husa P. Aktuality v léčbě a prevenci klostridiové kolitidy. Vnitř Lék 2020; 66(E-2): 24-28.

2. Oren A, Rupnik M. Clostridium difficile and Clostridioides difficile: Two validly published and correct names. Anaerobe 2018; 52: 125-126.

3. European Centre for Disease Prevention and Control. Point prevalence survey of healthcare-associated infections and antimicrobial use in European acute care hospitals. Stockholm: ECDC, 2013.

4. Krůtová M, Nyč O. Updated Czech guidelines for the laboratory diagnosis of Clostridium difficile infections. Epidemiol Mikrobiol Imunol 2018; 67: 92-95.

5. Crobach MJ, Planche T, Eckert C, et al. European Society of Clinical Microbiology and Infectious Diseases: update of the diagnostic guidance document for Clostridium difficile infection. Clin Microbiol Infect 2016; 22: (Suppl. 4): S63-S81.

6. Krutova M, Matejkova J, Kuijper EJ, et al. Clostridium difficile PCR ribotypes 001 and 176 the common denominator of $C$. difficile infection epidemiology in the Czech Republic 2014. Euro Surveill 2016; 21, doi: 10.2807/1560-7917.ES.2016.21.29.30296.

7. Krutova M, Matejkova J, Drevinek P, et al. Increasing incidence of Clostridium difficile ribotype 001 associated with severe course of the infection and previous fluoroquinolone use in the Czech Republic, 2015. Eur J Clin Microbiol Infect Dis 2017 36: 2251-2258.

8. Davies KA, Longshaw CM, Davis GL, et al. Underdiagnosis of Clostridium difficile across Europe: the European, multicentre, prospective, biannual, point-prevalence study of podávání fluorochinolonů (7). Právě restrikce v používání této skupiny antibiotik byla označena jako hlavní účinné opatření vedoucí k poklesu výskytu epidemických, k flurochinolonům rezistentních ribotypů ve Velké Británii (16).

V prevenci rozvoje a přenosu CDI v nemocničním zařízení je nutná mezioborová spolupráce mikrobiologa, infektologa a epidemiologa. Reflektování nových poznatků z oblasti laboratorní diagnostiky, léčby, prevence a sledování výskytu CDI je kruciální pro zlepšení epidemiologické situace CDI v ČR.

Clostridium difficile infection in hospitalised patients with diarrhoea (EUCLID). Lancet Infect Dis 2014; 14: 1208-1219.

9. European Centre for Disease Prevention and Control. Clostridium difficile infections. In: ECDC. Annual epidemiological report for 2016. Stockholm, ECDC 2018.

10. Ooijevaar RE, van Beurden YH, Terveer EM, et al. Update of treatment algorithms for Clostridium difficile infection. Clin Microbiol Infect 2018; 24: 452-462.

11. McDonald LC, Gerding DN, Johnson S, et al. Clinical Practice Guidelines for Clostridium difficile Infection in Adults and Children: 2017 Update by the Infectious Diseases Society of America (IDSA) and Society for Healthcare Epidemiology of America (SHEA). Clin Infect Dis 2018; 66: 987-994.

12. Tschudin-Sutter S, Kuijper EJ, Durovic A, et al. Guidance document for prevention of Clostridium difficile infection in acute healthcare settings. Clin Microbiol Infect 2018; 24: 1051-1054. 13. Bauer MP, Notermans DW, van Benthem BH, et al. Clostridium difficile infection in Europe: a hospital-based survey. Lancet 2011; 377: 63-73.

14. Krutova M, Nyc O, Matejkova J, et al. Molecular characterisation of Czech Clostridium difficile isolates collected in 2013-2015. Int J Med Microbiol 2016; 306: 479-485.

15. Freeman J, Vernon J, Pilling S, et al. The ClosER study: results from a three-year pan-European longitudinal surveillance of antibiotic resistance among prevalent Clostridium difficile ribotypes, 2011-2014. Clin Microbiol Infect 2018; 24: 724-731.

16. Dingle KE, Didelot X, Quan TP, et al. Effects of control interventions on Clostridium difficile infection in England: an observational study. Lancet Infect Dis 2017; 17: 411-421. 